\title{
Analisis Kesesuaian Kawasan Terbangun Dengan Rencana Tata Ruang Wilayah Di Kawasan Sempadan Pantai Kabupaten Rembang
}

\author{
Analysis of Suitability Built Areas with Regional Spatial Plans in the Coastal Border Area of Rembang Regency \\ Asyfi'na Shofiyal Izza ${ }^{* 1}$, Cherie Bhekti Pribadi², Yanto Budisusanto ${ }^{3}$ \\ ${ }^{1,2,3}$ Departemen Teknik Geomatika, FTSLK-ITS, Kampus ITS Sukolilo, Surabaya, 60111, Indonesia \\ *Korespondensi penulis: asyfinashofiyalizza7g6@gmail.com
}

Diterima : 11082020; Diperbaiki : 02092020; Disetujui : 07092020; Dipublikasi : 13112020

\begin{abstract}
Abstrak: Kabupaten Rembang merupakan salah satu kawasan yang berada di pesisir pantai utara jawa dengan luas sebesar 101.408 ha yang secara geografis terletak pada 6o30'- 7o 6'LS dan 1110 - 111030' BT dengan garis pantai sepanjang $63 \mathrm{~km}$. Panjangnya garis pantai di Kabupaten Rembang memungkinkan banyaknya aktivitas di wilayah pesisir yang akan berdampak pada banyaknya penggunaan lahan yang tidak sesuai dengan ketentuan semestinya yang banyak mengakibatkan abrasi. Fenomena abrasi yang terjadi pada 30 agustus 2019 di Kecamatan Kragan Kabupaten Rembang yang mengikis pantai sejauh $15 \mathrm{~m}$ dengan panjang 1,5 km. Mengingat besarnya ancaman bencana abrasi yang melanda Kabupaten Rembang maka perlu adanya evaluasi penggunaan lahan pada wilayah pesisir terutama di kawasan sempadan pantai. Pada penelitian ini akan dilakukan analisis mengenai kesesuaian kawasan terbangun (Land Use) di area sempadan pantai dengan peta rencana tata ruang wilayah (Land Development). Selanjutnya akan ditampilkan dalam bentuk ArcGIS Online yang akan memudahkan dalam mengakses peta. Hasil dari penelitian yang dilakukan diperoleh empat kelas pada peta rencana tata ruang wilayah yaitu berupa peruntukan pemukiman, industri, sempadan pantai, dan hutan. Selanjutnya luas tertinggi kesesuaian rencana tata ruang wilayah (RTRW) dan kondisi eksisiting adalah untuk kelas industri sebesar 163,497 Ha, pemukiman sebesar 45,798 Ha, sedangkan untuk peruntukan sempadan pantai dan hutan tidak ada luasan yang sesuai dengan rencana tata ruang wilayahnya.
\end{abstract}

Copyright $\odot 2020$ Geoid. All rights reserved.

\begin{abstract}
Rembang Regency is one of the areas that located on the north coast of Java Sea with an area of 101.408 Ha which is geographic located at 6o30'- 7o 6'S dan 111o-111030' E and coastline 63 Km from Kaliori to Sarang. The magnitude of the coastline in Rembang Regency make amount of activity in the Coastal region which will have an impact on the amount of land use that is not in accordance with the plan, make abrasion happened. As on August 30, 2019, abrasion occurred in Kragan, Rembang Regency, which eroded the coast as far as 15 with a length of 1.5 $\mathrm{km}$. Given the magnitude of the emergency abrasion problem that is affecting Rembang Regency, it is necessary to evaluate land use expecially in coastal areas. In this study an analysis will be made of the suitability of the built area (Land Use) in the coastal border area with a regional spatial plan map. Furthermore, it will facilitate in the form of ArcGIS Online which will facilitate accessing maps. The results of the research carried out obtained four classes on the spatial map of the territory consisting of the allotment of settlements, industry, coastal borders, and forests. Furthermore, the area in accordance with the suitability of the spatial plan and the existing conditions for the industrial class is $163.497 \mathrm{Ha}$, settlement is $45.798 \mathrm{Ha}$, while for the designation of the coast and forest border there is an area in accordance with the spatial plan of the area.
\end{abstract}

Kata kunci : Sempadan Pantai; RTRW; Kawasan Terbangun

\section{Pendahuluan}

Kabupaten Rembang merupakan salah satu kawasan yang berada di pesisir pantai utara jawa dengan luas sebesar 101.408 ha yang secara geografis terletak pada $6^{\circ} 30^{\prime}-7^{\circ} 6^{\prime}$ LS dan $111^{\circ}-111^{\circ} 30^{\prime}$ BT dengan garis pantai sepanjang $63 \mathrm{~km}$ yang membentang dari Kaliori hingga Sarang (Roziqin, 2016). Kabupaten Rembang menjadi salah satu wilayah pesisir yang intensif digunakan untuk kegiatan manusia sebagai kawasan pusat pemerintahan, pemukiman, industri, pelabuhan, pertambakan, pertanian, perikanan, pariwisata dan sebagainya (Pranoto, 2007) sehingga dengan panjangnya garis pantai di Kabupaten Rembang memungkinkan banyaknya 
aktivitas di wilayah pesisir. Adanya berbagai kegiatan tersebut dapat menimbulkan peningkatan kebutuhan akan lahan, sarana dan prasarana (Iskandar \& dkk, 2016). Sehingga pemerintah menetapkan acuan teknis dalam pembangunan wilayah berupa peraturan perundangan No. 26 Tahun 2007 tentang pemanfaatan ruang pada suatu wilayah yang kemudian dituangkan dalam bentuk peta, yaitu Peta Rencana Tata Ruang Wilayah. Dengan adanya peta tersebut, pemerintah dapat mengontrol, mengawasi dan merencanakan pengelolaan dan penggunaan lahan wilayah dengan baik (Luthfina, 2019). Selain peraturan perundangan tentang pemanfaatan ruang, acuan lain yang digunakan dalam pengelolaan wilayah pesisir adalah peraturan mengenai kawasan sempadan pantai. Sesuai Peraturan Presiden No.51 Tahun 2016, batas sempadan pantai merupakan dataran sepanjang tepian pantai yang lebarnya proporsional dengan bentuk dan kondisi fisik pantai dengan minimal 100 (seratus) meter dari titik pasang tertinggi ke arah darat. Dengan banyaknya aktivitas yang dilakukan di kawasan pesisir, akan berdampak pada banyaknya penggunaan lahan yang tidak sesuai dengan ketentuan semestinya seperti kawasan terbangun yang banyak mengakibatkan abrasi. Fenomena abrasi yang terjadi pada 30 Agustus 2019 di Kecamatan Kragan Kabupaten Rembang yang mengikis pantai sejauh 15 m dengan panjang 1,5 km (Asmui, 2019). Mengingat besarnya ancaman bencana abrasi yang melanda Kabupaten Rembang maka perlu adanya evaluasi penggunaan lahan pada wilayah pesisir terutama di kawasan sempadan pantai.

Namun pada kenyataannya masih sering dijumpai kawasan yang tidak sesuai dengan semestinya, seperti kawasan sempadan pantai yang seharusnya digunakan sebagai wilayah konservasi tetapi justru dialih fungsikan menjadi kawasan terbangun dan dengan banyaknya kawasan terbangun yang ada akibatnya kawasan pesisir banyak terjadi erosi. Begitupun yang terjadi di kawasan pesisir Kabupaten Rembang.

Oleh karena itu, pada penelitian ini akan dilakukan analisis mengenai kesesuaian kawasan terbangun di area sempadan pantai dengan rencana tata ruang dengan menginterpretasi citra satelit resolusi tinggi yang kemudian disajikan dalam bentuk ArcGIS online. Hasil akhir yang diperoleh dari penelitian ini berupa peta kesesuaian kawasan terbangun terhadap rencana tata ruang wilayah yang berada di wilayah sempadan pantai Kabupaten Rembang.

\section{Data dan Metode}

Lokasi penelitian berada di wilayah pesisir Kabupaten Rembang yang secara geografis terletak pada koordinat $6^{\circ} 30^{\prime}-7^{\circ} 6^{\circ} \mathrm{LS}$ dan $111^{\circ}-111^{\circ} 30^{\prime}$ BT dengan garis pantai sepanjang $63 \mathrm{~km}$.

Selanjutnya untuk data yang digunakan dalam penelitian ini adalah area penelitian berada di di area sempadan pantai kawasan pesisir Kabupaten Rembang, analisis data dilakukan berdasarkan PEPRES No.51 Tahun 2016 mengenai Batas Sempadan Pantai dan UU No. 26 Tahun 2007 mengenai Rencana Tata Ruang Wilayah, penelitian ini menggunakan data spasial citra satelit Pleiades 2017 yang diperoleh dari BPN Kabupaten Rembang, Peta Rencana Tata Ruang Wilayah (RTRW) Kabupaten Rembang Tahun 2011 - 2031 yang diperoleh dari Dinas Pekerjaan Umum Kabupaten Rembang.

Adapun alat yang digunakan dalam proses pengolahan data berupa software pengolahan data spasial dan pengolahan kata. Tahap pertama yang dilakukan identifikasi Peta Rencana . Selanjutnya dilakukan proses penampalan garis pantai dengan citra Satelit Pleiades Kabupaten Rembang Tahun 2017, buffer data garis pantai dilakukan sebesar 100 meter untuk menjadi acuan dalam penentuan kawasan sempadan pantai.

Tahap selanjutnya melakukan digitasi citra satelit yang untuk kawasan terbangun di area sempadan pantai. Berdasarkan hasil digitasi diperoleh sebanyak 11 kelas yaitu kelas industri, lahan, lapangan, laut, mangrove, pemukiman, taman, tambak, jalan, sungai, dan pekarangan. Kemudian menganalisis ketertiban administrasi pertanahan terhadap zona nilai tanah dan data status atas tanahnya. Selanjutnya pada tahap terakhir berupa penyusunan laporan penelitian agar hasil penelitian ini dapat bermanfaat dan diketahui oleh orang lain. Selain dengan pembuatan laporan dilakukan pula pembuatan peta dalam format online. 


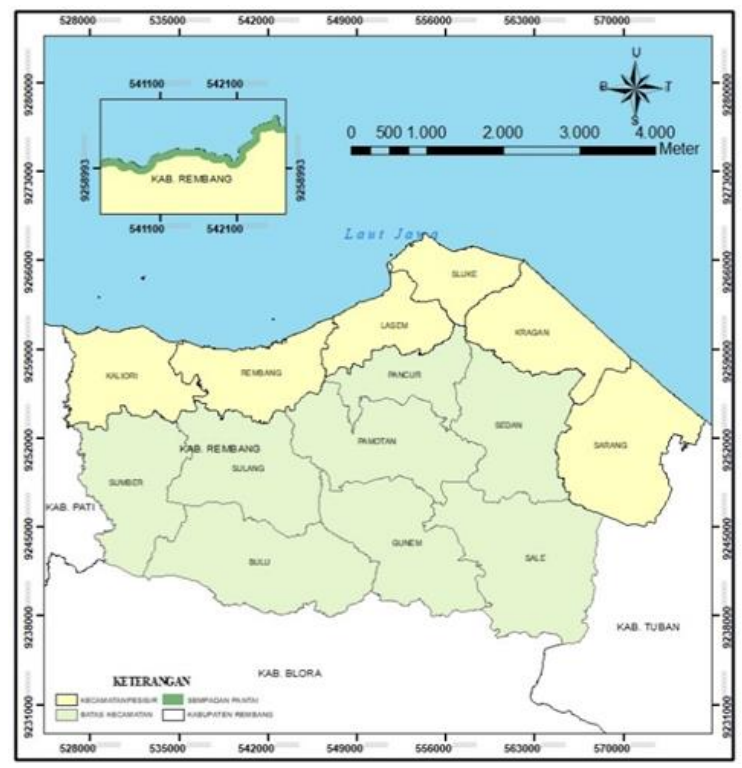

Gambar 1. Lokasi Penelitian

\section{Hasil Dan Pembahasan}

Berdasarkan interpretasi yang telah dilakukan diperoleh data luas tutupan lahan pada peta RTRW untuk wilayah sempadan pantai adalah sebagai berikut.

\section{Luas (Ha)}

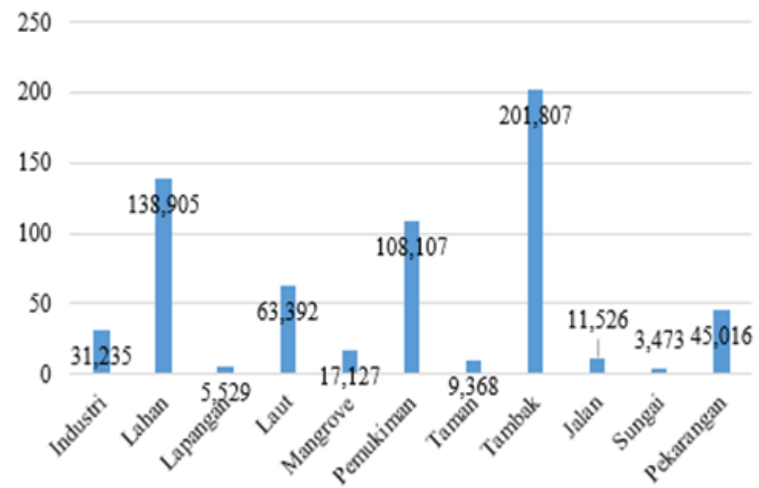

Gambar 2. Luas Tutupan Lahan di Wilayah Sempadan Pantai

Berdasarkan Gambar 2. Diperoleh total keseluruhan luas tutupan lahan di wilayah sempadan pantai Kabupaten Rembang sebesar 635,485 Ha dengan jumlah kelas sebanyak 11 kelas. Kelas yang memiliki luas terbesar adalah tambak sebesar 201,807 Ha dari luas sempadan pantai Kabupaten Rembang. Sedangkan untuk luas terkecil pada kelas sungai yaitu hanya sebesar 3,473 Ha dari total keseluruhan luas wilayah sempadan pantai Kabupaten Rembang.

Selanjutnya apabila dihitung untuk luas kelas pada peta RTRW adalah sebagai berikut : 


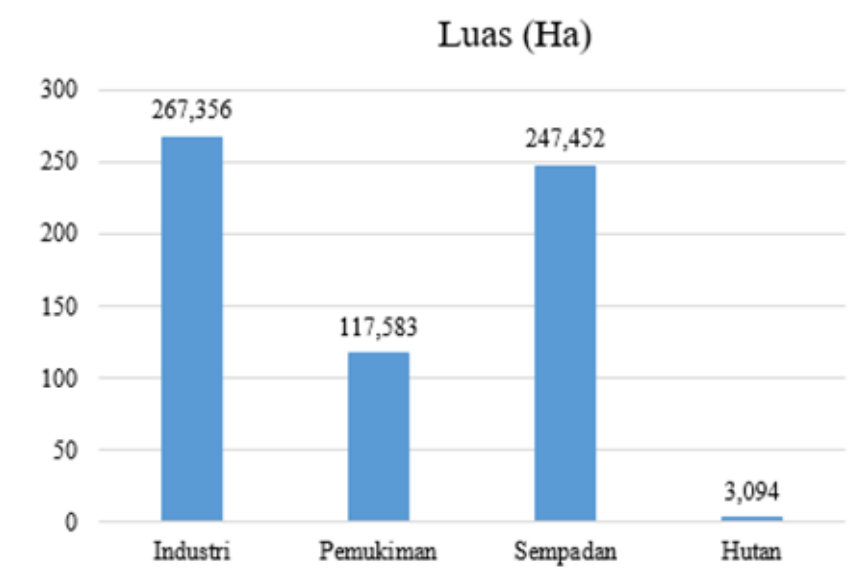

Gambar 3. Luas Kelas Pada Peta RTRW Di Wilayah Sempadan Pantai

Dari Gambar 2 dapat diperoleh bahwa jumlah kelas pada peta RTRW hanya 4 kelas dengan luas tertinggi pada kelas industri sebesar 267,356 Ha dan luas terendah pada kelas hutan sebesar 3,094 Ha. Selanjutnya apabila Gambar 2. dijabarkan berdasarkan wilayah kecamatannya adalah sebagai berikut.

\begin{tabular}{lll}
\multicolumn{2}{l}{ Tabel 1. Luas RTRW di Wilayah Sempadan Pantai per Kecamatan } \\
\hline Kecamatan & Kelas RTRW & Luas (Ha) \\
\hline \multirow{2}{*}{ Kaliori } & Industri & 90,324 \\
& Pemukiman & 12,927 \\
\hline \multirow{2}{*}{ Rembang } & Pemukiman & 104,656 \\
& Industri & 37,347 \\
\hline \multirow{2}{*}{ Lasem } & Industri & 65,488 \\
& Hutan & 3,094 \\
\hline \multirow{2}{*}{ Sluke } & Industri & 74,197 \\
& Sempadan Pantai & 55,692 \\
\hline Kragan & Sempadan Pantai & 115,490 \\
\hline Sarang & Sempadan Pantai & 76,270 \\
\hline Total & & $\mathbf{6 3 5 , 4 8 5}$ \\
\hline
\end{tabular}

Apabila dibandingkan dengan kondisi tahun 2017 yang ada banyak terdapat perbedaan, mulai dari perbedaan jumlah kelas yang ada dimana pada peta rencana hanya terdapat 4 kelas sedangkan untuk kondisi terbarunya terdapat 11 kelas. Berdasarkan perbedaan jumlah kelas yang ada maka dapat disimpulkan bahwa terdapat perubahan fungsi tutupan lahan yang tidak sesuai dengan rencana tata ruangnya. Dimana perubahan fungsi lahannya ditunjukkan dalam tabel berikut.

Tabel 2. Perbedaan RTRW dan Kondisi Eksisting

\begin{tabular}{lll} 
RTRW & Kondisi Eksisting & \multicolumn{1}{c}{ Keterangan } \\
\hline & & $\begin{array}{l}\text { Berdasarkan dokumen RTRW di wilayah } \\
\text { sempadan pantai Kecamatan Kragan, } \\
\text { Sarang dan sebagian wilayah Kecamatan }\end{array}$ \\
& Sluke seharusnya diperuntukkan sebagai \\
& Kawasan Sempadan Pantai tetapi sesuai \\
kondisi eksisting yang ada wilayah tersebut \\
digunakan sebagai kawasan pemukiman \\
dan lahan pertanian.
\end{tabular}




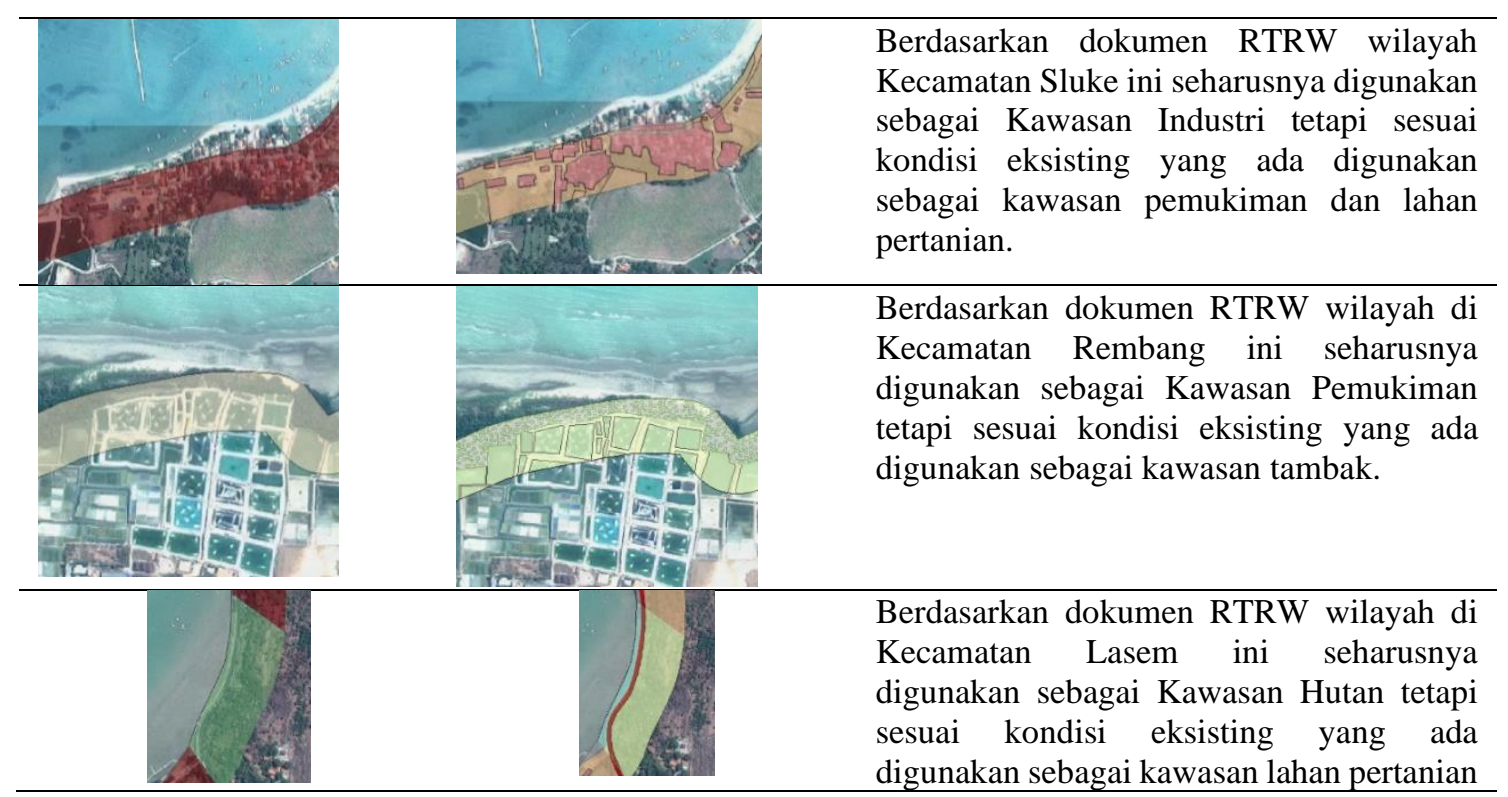

Perubahan Luas dalam penggunaan lahan yang tidak sesuai dengan rencana tata ruang wilayah ditunjukkan oleh Tabel 3. berikut ini.

Tabel 3. Kesesuaian RTRW dan Kondisi Eksisiting

\begin{tabular}{llr}
\hline & Keterangan & \multicolumn{1}{c}{ Luas (Ha) } \\
\hline \multirow{2}{*}{ Pemukiman } & Sesuai RTRW & 45,798 \\
& Tidak Sesuai RTRW & 71,785 \\
\hline \multirow{2}{*}{ Industri } & Sesuai RTRW & 163,497 \\
& Tidak Sesuai RTRW & 103,859 \\
\hline \multirow{2}{*}{ Sempadan } & Sesuai RTRW & - \\
Pantai & Tidak Sesuai RTRW & 247,452 \\
\hline \multirow{2}{*}{ Hutan } & Sesuai RTRW & - \\
& Tidak Sesuai RTRW & 3,094 \\
\hline Total & & $\mathbf{6 3 5 , 4 8 5}$ \\
\hline
\end{tabular}

Berdasarkan Tabel 3. dapat diperoleh bahwa kawasan yang memiliki luas tertinggi sesuai dengan RTRW adalah peruntukan industri sebesar 163,497 Ha dan pada peruntukan pemukiman sebesar 45,798 Ha sesuai dengan RTRW. Sedangkan untuk peruntukan sempadan pantai dan hutan tidak ada yang sesuai dengan peruntukannya.

Selanjutnya apabila dijelaskan berdasarkan kecamatan maka sebagai berikut.

Tabel 4. Kesesuaian RTRW per Kecamatan

\begin{tabular}{lrr}
\hline \multicolumn{3}{c}{ Kesesuaian } \\
\hline Kecamatan & $\begin{array}{c}\text { Sesuai RTRW } \\
\text { (Ha) }\end{array}$ & $\begin{array}{c}\text { Tidak Sesuai RTRW } \\
\text { (Ha) }\end{array}$ \\
\hline Kaliori & 12,971 & 89,097 \\
Rembang & 139,057 & 9,592 \\
Lasem & - & 79,809 \\
Sluke & 57,267 & 65,374 \\
Kragan & - & 112,001 \\
Sarang & - & 70,317 \\
\hline Total & $\mathbf{2 0 9 , 2 9 5}$ & $\mathbf{4 2 6 , 1 9 0}$ \\
\hline
\end{tabular}


Berdasarkan Tabel 4. secara keseluruhan luas wilayah yang sesuai dengan RTRW sebesar 209,295 Ha dan yang tidak sesuai dengan RTRW sebesar 426,190 Ha.

Hasil dari penelitian ini juga ditampilkan pada ArcGIS Online. ArcGIS Online merupakan layanan web yang dapat digunakan dalam menampilkan peta secara online. Data yang ditampilkan dalam ArcGIS Online ini berupa data hasil overlay data tutupan lahan sebagai data eksisting, data Rencana Tata Ruang Wilayah (RTRW), data status tanah, serta data nilai tanah. Hasil ArcGIS Online berupa peta interaktif yang dapat diakses melalui link berikut :

http://www.arcgis.com/apps/InteractiveLegend/index.html?appid=e7d47eff13964a3997484aa5bc179df2 serta dapat dilihat pada gambar berikut :

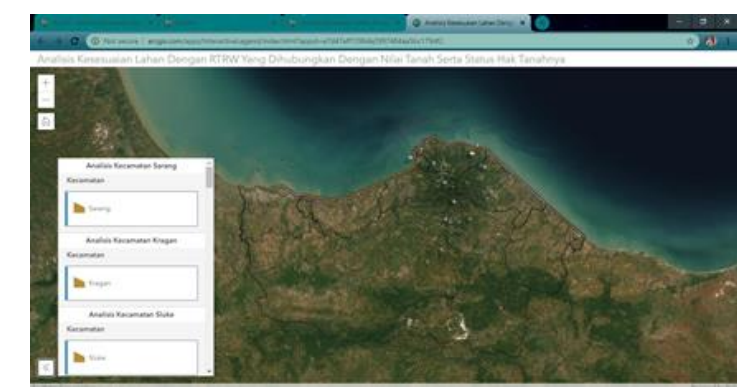

Gambar 4. Hasil Overlay Data Di ArcGIS Online

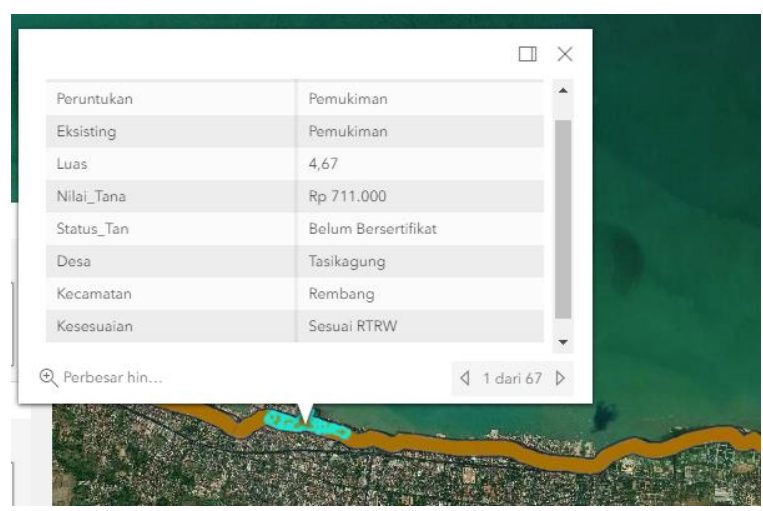

Gambar 5. Informasi Di ArcGIS Online

Hasil yang ditampilkan dalam peta online ini berupa kesesuaian lahan dengan Rencana Tata Ruang Wilayah (RTRW). Menu yang terdapat pada peta online ini berupa judul peta, menu memperbesar dan memperkecil peta, legenda peta. Informasi yang ditampilkan pada peta online ini berupa kondisi tutupan lahan yang meliputi kelas industri, lahan, lapangan, laut, mangrove, pemukiman, taman, tambak, jalan, sungai, dan pekarangan. Selain itu juga terdapat informasi mengenai kesesuaian rencana tata ruang dan wilayah dengan kondisi tutupan lahan serta batas administrasi.

\section{Kesimpulan}

Dari penelitian ini dapat disimpulkan bahwa kawasan yang diperuntukkan sempadan pantai adalah 247,452 Ha dan kawasan peruntukan hutan sebesar 3,094 Ha yang tidak digunakan sesuai RTRWnya. Selain itu kawasan yang sesuai dengan RTRW peruntukan pemukiman sebesar 45,798 Ha dan peruntukan industri sebesar 163,497 Ha. Selain itu hasil yang ditampilkan dalam ArcGIS Online dapat memudahkan dalam mengakses data hasil analisis. Hasil yang ditampilkan dalam peta online ini berupa kesesuaian lahan dengan Rencana Tata Ruang Wilayah (RTRW) yang dapat diakses pada link berikut: http://www.arcgis.com/apps/InteractiveLegend/index.html?appid=e7d47eff13964a3997484aa5bc179df2. 


\section{Ucapan Terima Kasih}

Penulis mengucapkan terimakasih kepada Kantor ATR/BPN Kabupaten Rembang yang telah memberikan bantuan data dalam penelitian ini.

\section{Daftar Pustaka}

Asmui. 2019. Gelombang Tinggi Pantai Pandangan Diterjang Abrasi. Retrieved from http://cbfrembang.com/gelombangtinggi-pantai-pandangan-diterjang-abrasi/

Iskandar, F., \& dkk. 2016. Analisis Kesesuaian Penggunaan Lahan TErhadap Rencana Tata Ruang WIlayah di Kecamatan Kutoarjo Menggunakan Sistem Informasi Geografis. Teknik Geodesi Universitas Diponegoro.

Luthfina, M. 2019. Analisis Kesesuaian Penggunaan Lahan Terhadap Rencana Tata Ruang Wilayah Tahun 2010 - 2030 Menggunakan Sistem Informasi Geografis di Kecamatan Pati. Jurnal Teknik Geodesi Universitas Diponegoro.

Pranoto, S. 2007. Prediksi Perubahan Garis Pantai Menggunakan Model Genesi. Berkala Ilmiah Teknik Keairan, Vol. 13 No. 3.

Roziqin, A. 2016. Evaluasi Dampak Kebijakan Pengelolaan WIlayah Pesisir dan Laut di Kabupaten Rembang. Semarang: Jurnal Administrasi Publik, FISIP Universitas Diponegoro. 